\title{
Pengguna Jasa Angkutan Umum Jenis Angkot Di Jakarta Dalam Perspektif Hukum Perlindungan Konsumen
}

(Users of Public Transportation Services (Angkot) at Jakarta In Consumer Protection Law Perspective)

\author{
Faris Satria Alam \\ FSH UIN Syarif Hidayatullah Jakarta \\ Jl. Ir. H. Juanda No. 95 Ciputat Tangerang Selatan \\ Email: faris satria@yahoo.co.id
}

doi $\underline{10.15408 / \text { sjsbs.v3i2.7857 }}$

\begin{abstract}
:
In reality, consumer as users and passenger's public transportation (Angkot) have not received legal protection and maximum service that should be given regarding the application of minimum service standards. Besides, there are still problems related to public transportation service sector in the form of the decision of public transportation tariff that has not been matched by the availability of public transportation, the proper of public transportation and consumer safety from crime over public transportation. The result of this study explains that public transportation (Angkot) still has many weaknesses especially related to the implementation of minimum service standards.
\end{abstract}

Keywords: Public Transportation, Angkot, Consumer Protection.

\begin{abstract}
Abstrak:
Konsumen sebagai pengguna jasa maupun penumpang angkutan umum jenis angkot pada realitasnya belum mendapat perlindungan hukum dan pelayanan maksimal yang seharusnya diberikan berupa penerapan standar pelayanan minimal. Disamping masih adanya persoalan mengenai sektor pelayanan angkutan umum berupa: penetapan tarif angkutan umum yang belum atau tidak diimbangi dengan ketersediaan jumlah angkutan umum; kelaikan kendaraan angkutan umum; dan keamanan konsumen dari kejahatan di atas kendaraan angkutan umum. Hasil penelitian ini menjelaskan bahwa selama ini pelayanan angkutan umum jenis angkot ini masih memiliki banyak kekurangan terutama menyangkut penerapan standar pelayanan minimal.
\end{abstract}

Kata Kunci: Angkutan Umum, Jenis Angkot, Perlindungan Konsumen.

${ }^{*}$ Diterima tanggal naskah diterima: 10 Maret 2016, direvisi: 20 April 2016, disetujui untuk terbit: 15 Mei 2016. 


\section{Pendahuluan}

Transportasi atau pengangkutan merupakan suatu bidang kegiatan yang sangat penting dalam kehidupan masyarakat Indonesia. Pentingnya transportasi bagi masyarakat Indonesia disebabkan oleh beberapa faktor antara lain, keadaan geografis Indonesia yang terdiri dari ribuan pulau kecil dan besar (archipelago), perairan yang terdiri dari sebagian besar laut, sungai dan danau yang memungkinkan pengangkutan dilakukan melalui darat, laut, dan udara guna menjangkau seluruh wilayah negara. ${ }^{1}$ Dari sekian banyak jasa yang ditawarkan kepada konsumen, salah satu jasa yang paling sering digunakan atau dinikmati konsumen adalah jasa transportasi angkutan umum jenis angkot yang ada di Jakarta. Sekelumit persoalan mengenai sektor pelayanan angkutan umum yang masih menyimpan persoalan-persoalan klasik berupa: 1) penetapan tarif angkutan umum (misal, kenaikan tarif) yang belum atau tidak diimbangi dengan ketersediaan jumlah angkutan umum; 2) kelaikan kendaraan angkutan umum (menyangkut soal keamanan konsumen; 3) keamanan konsumen dari kejahatan di atas kendaraan angkutan umum. ${ }^{2}$

Wajah angkutan umum di Jakarta tak ubahnya sebuah tontonan yang tak beradab, bahkan menunjukkan prilaku yang barbarian. Pemerkosaan dan pembunuhan yang baru-baru ini terjadi adalah fenomena yang tak terbantahkan. Tentu saja, kasus primitif ini amat menghentak kesadaran publik di Jakarta, bahkan seantero negeri. Namun demikian, potret buram kualitas pelayanan angkutan umum di perkotaan, sejatinya bukan tipikal kota Jakarta saja. Nyaris di seluruh kota besar di Indonesia, kualitas pelayanan angkutan umumnya amburadul dan tidak beradab. ${ }^{3}$ Wajar kalau kemudian secara perlahan tetapi pasti warga tidak berminat menggunakan angkutan umum dan kemudian meninggalkannya. Di Jakarta pada tahun 2005 kepeminatan warga Jakarta dalam menggunakan angkutan umum masih 38\%, tetapi pada data tahun 2010 kepeminatan itu turun drastis, hanya $11,5 \%{ }^{4}$ Sebenarnya dengan tersedianya transportasi massal yang memadai yaitu memenuhi syarat aman, nyaman, dan tepat waktu, kami yakin konsumen tidak berkeberatan untuk menggunakannya. Heterogenitas masyarakat kita perlu dijawab dengan penyediaan transportasi

\footnotetext{
${ }^{1}$ Abdulkadir Muhammad, Hukum Pengangkutan Niaga, (Bandung: PT. Citra Aditya Bakti, 1998), h. 7.

2 Yusuf Shofie, Kapita Selekta Hukum Perlindungan Konsumen di Indonesia, (Jakarta: PT. Citra Aditya Bakti, 2008), h. 10.

3 Tulus Abadi, Berlomba Mematikan Angkutan Umum, sebagaimana di akses dari http://www.ylki.or.id/berlomba-mematikan-angkutan-umum.html pada 15 September 2012 Jam 09.23 WIB. Lihat juga Suara Pembaruan, Berlomba Mematikan Angkutan Umum, Senin, 3 Oktober 2011.

4 Tulus Abadi, Subsidi BBM dan Nasib Angkutan Umum, sebagaimana di akses dari http://www.ylki.or.id/ subsidi-bbm-dan-nasib-angkutan-umum.html pada 18 September 2012 Jam 15.10 WIB. Lihat juga Seputar Indonesia, Berlomba Mematikan Angkutan Umum, Rabu, 28 Maret 2012.
} 
umum yang bervariasi, mulai dari yang kelas rakyat, sampai untuk konsumen berdasi. $^{5}$

Kesadaran pengemudi angkutan umum di wilayah hukum Polda Metro Jaya masih terbilang rendah. Padahal, disiplin berlalu lintas terbilang penting untuk meningkatkan keamanan dan kenyamanan. Ketidakdisiplinan pengemudi angkutan umum ini terbukti dari banyaknya angkutan umum yang terjaring dalam Operasi Patuh Jaya 2012. Berdasarkan data Direktorat Lalu Lintas Polda Metro Jaya pada tanggal 16-23 Juli 2012, ada 7.727 kasus pelanggaran yang melibatkan angkutan umum. Dari 7.727 kasus pelanggaran yang melibatkan angkutan umum itu, jenis pelanggaran yang paling banyak dilakukan adalah melanggar rambu lalu lintas letter $P$ (dilarang parkir) sebanyak 2.927 kasus pelanggaran. Selanjutnya disusul dengan pelanggaran turun atau naik penumpang tidak pada tempatnya sebanyak 2.250 kasus pelanggaran. Sementara pelanggaran rambu letter $S$ (dilarang berhenti) mencapai 1.734 kasus, menerobos jalur busway ada 772 kasus, dan omprengan yang menggunakan plat hitam sebanyak 44 kasus. ${ }^{6}$

Dari data yang dimiliki Polda Metro Jaya, jumlah perjalanan harian semakin meningkat setiap tahunnya. Seperti pada tahun 2009 tercatat rata-rata 620.702 jumlah perjalanan dan pada tahun 2010 naik menjadi 791.295 jumlah perjalanan. Diperkirakan pada tahun 2020 mendatang naik menjadi 1.148.528 jumlah perjalanan. Sementara, untuk jumlah angkutan umum yang beroperasi di Ibukota hanya berjumlah 76.022 kendaraan. Sedangkan data dari Dinas Perhubungan DKI Jakarta dan Organda DKI terdapat sedikitnya 22.776 angkutan umum jenis bus besar, sedang dan bus kecil dinilai telah berusia uzur, bahkan 16.460 bus diantaranya. ${ }^{7}$

Salah satu langkah yang harus dilakukan Pemerintah Provinsi Ibukota Jakarta dalam membenahi karut marutnya transportasi yakni dengan membuat Standar Pelayanan Minimal (SPM) bagi angkutan umum di Jakarta. Azas Tigor Nainggolan yang saat ini menjabat sebagai Ketua Dewan Transportasi Kota Jakarta, berpendapat bahwa SPM itu perlu sebagai bagian dari revitalisasi angkutan umum di ibukota serta juga berguna melindungi hak konsumen atau pengguna angkutan umum. Sebab bila tanpa SPM maka konsumen sebagai pengguna angkutan umum akan banyak terlanggar hak-haknya seperti sekarang ini. Undang-Undang Nomor 22 tahun 2009 tentang lalu lintas dan angkutan jalan

${ }^{5}$ Zumrotin K. Susilo, Penyambung Lidah Konsumen, Cet. I, (Jakarta: Puspa Swara, 1996), h. 104.

${ }^{6}$ Sudarmanto, Kesadaran Supir Angkot di Jakarta Masih Rendah, sebagaimana di akses dari http://m.skalanews.com/baca/news/2/34/118658/megapolitan/kesadaran-supir-angkot-di-jakartamasih-rendah.html pada 18 September 2012 Jam 15.00 WIB.

7 Wahyono, Polda Desak Pengusaha Angkutan Remajakan Armadanya, sebagaimana di akses darihttp://m.skalanews.com/baca/news/2/34/103862/megapolitan/polda-desak-pengusahaangkutan-remajakan-armadanya-.html pada 18 September 2012 Jam 15.30 WIB. 
mengatur bahwa perusahaan angkutan umum wajib memenuhi standar pelayanan minimal termasuk keamanan, keselamatan, kenyamanan, keterjangkauan, kesetaraan, dan keteraturan. ${ }^{8}$ Oleh karena itu, Dinas perhubungan pemerintah provinsi DKI Jakarta tinggal mengadopsi dan mengimplementasikan saja aturan SPM tersebut di Jakarta. ${ }^{9}$

Dengan telah disahkannya Peraturan Menteri Perhubungan No. 10 tahun 2012 tentang Standar Pelayanan Minimal Angkutan Massal Berbasis Jalan pada tanggal 31 januari 2012 ${ }^{10}$, sebenarnya pemenuhan terhadap hak-hak dasar konsumen sebagai pengguna angkutan umum, yaitu kenyamanan, keamanan dan keselamatan dapat terwujud dan bukan hanya menjadi sebuah dongeng belaka. Padahal hak pengguna angkutan umum di Indonesia sejatinya mendapatkan jaminan yang amat kokoh, mulai dari undang-undang no. 8 tahun 1999 tentang perlindungan konsumen dan undang-undang no. 22 Tahun 2009 tentang lalu lintas dan angkutan jalan serta berbagai regulasi teknis pendukung lainnya. Buruknya kualitas pelayanan angkutan umum di perkotaan tidak bisa dilihat secara sektoral saja. Artinya, bukan semata kesalahan dinas perhubungan dan pengusaha angkutan umum. Bahkan pula ketidakmampuan pemimpin kota/daerah ansich. Akan tetapi melibatkan semua stakeholder, mulai dari pemerintah, pelaku usaha, dan masyarakat sebagai konsumen tentunya.

\section{Hukum Pengangkutan dan Hukum Perlindungan Konsumen di Indonesia}

Dalam kegiatan sehari-hari kata pengangkutan sering diganti dengan kata" transportasi". Pengangkutan lebih menekankan pada aspek yuridis sedangkan transportasi lebih menekankan pada aspek kegiatan perekonomian, akan tetapi keduanya memiliki makna yang sama, yaitu sebagai kegiatan pemindahan dengan menggunakan alat angkut. Abdulkadir Muhammad mendefinisikan pengangkutan sebagai proses kegiatan pemindahan penumpang dan/atau barang dari suatu tempat ke tempat lain dengan menggunakan berbagai jenis alat pengangkut mekanik yang diakui dan diatur undang-undang sesuai dengan bidang angkutan dan kemajuan teknologi. ${ }^{11}$ Selanjutnya ia menambahkan bahwa pengangkutan memiliki tiga dimensi pokok, yaitu

${ }^{8}$ Lihat Pasal 141, Undang-Undang Nomor 22 Tahun 2009 Tentang Lalu Lintas dan Angkutan Jalan, Lembaran Negara Republik Indonesia Tahun 2009 Nomor 96, Tambahan Lembaran Negara Nomor 5025.

${ }_{9}$ Azas Tigor Nainggolan, Jakarta Perlu Standar Pelayanan Minimum, sebagaimana di akses dari http://m.skalanews.com/baca/news/2/34/119757/megapolitan/jakarta-perlu-standar-minimunpelayanan angkutan-umum-.html Artikel diakses pada 18 September 2012 Jam 15.20 WIB.

${ }^{10} \mathrm{http}: / / 118.97 .61 .233 /$ perundangan/index.php?option=com dirhukum\&task=view\&id=889 \&Itemid=55559 sebagaimana di akses dari www.dephub.go.id Artikel diakses pada 19 September 2012 Jam 15.00 WIB.

11 Abdulkadir Muhammad, Arti Penting dan Strategis Multimoda Pengangkutan Niaga di Indonesia Dalam Perspektif Hukum Bisnis di Era Globalisasi Ekonomi, (Yogyakarta:Penerbit Genta Press, 2007), h. 1. 
pengangkutan sebagai usaha, pengangkutan sebagai perjanjian dan pengangkutan sebagai proses. ${ }^{12}$ Pengangkutan sebagai usaha memiliki ciri-ciri sebagai berikut: (1) Berdasarkan suatu perjanjian; (2) Kegiatan ekonomi di bidang jasa; (3) Berbentuk perusahaan; (4) Menggunakan alat angkut mekanik. Sedangkan pengangkutan sebagai perjanjian, pada umumnya bersifat lisan (tidak tertulis) tetapi selalu didukung oleh dokumen angkutan. Pengangkutan sebagai proses mengandung makna sebagai serangkaian perbuatan mulai dari pemuatan ke dalam alat angkut, kemudian dibawa menuju tempat yang telah ditentukan, dan pembongkaran atau penurunan di tempat tujuan. ${ }^{13}$

Transportasi atau pengangkutan dapat dikelompokan menurut macam atau moda atau jenisnya (modes of transportation) yang dapat ditinjau dari segi barang yang diangkut, dari segi geografis transportasi itu berlangsung, dari sudut teknis serta dari sudut alat angkutannya. Bentuk klasifikasi transportasi sebagai berikut ${ }^{14}$ : Pertama, Dari segi barang yang diangkut, transportasi meliputi: (a) angkutan penumpang (passanger); (b) angkutan barang (goods); (c) angkutan pos (mail). Kedua, Dari sudut geografis. transportasi dapat dibagi menjadi: (a) Angkutan antar benua: misalnya dari Asia ke Eropa; (b) Angkutan antar kontinental: misalnya dari Francis ke Swiss dan seterusnya sampai ke Timur Tengah; (c) Angkutan antar pulau: misalnya dari Pulau Jawa ke Pulau Sumatera; (d) Angkutan antar kota: misalnya dari Jakarta ke Bandung; (e) Angkutan antar daerah: misalnya dari Jawa Barat ke Jawa Timur; (f) Angkutan di dalam kota: misalnya kota Medan, Surabaya dan lain-lain. Ketiga, Dari sudut teknis dan alat pengangkutnya, Jika dilihat dari sudut teknis dan alat angkutnya, maka transportasi dapat dibedakan sebagai berikut: (a) Angkutan jalan raya atau highway transportation (road transportation), seperti pengangkutan dengan menggunakan truk, bus, dan sedan; (b) Pengangkutan rel (rail transportation), yaitu angkutan kereta api, trem listrik dan sebagainya. Pengangkutan jalan raya dan pengangkutan rel kadang-kadang keduanya digabung dalam golongan yang disebut rail and road transportation atau land transportation (angkutan darat); (c) Pengangkutan melalui air di pedalaman (inland transportation), seperti pengangkutan sungai, kanal, danau, dan sebagainya; (d) Pengangkutan pipa (pipe line transportation), seperti transportasi untuk mengangkut atau mengalirkan minyak tanah, bensin, dan air minum; (e) Pengangkutan laut atau samudera (ocean transportation), yaitu angkutan dengan menggunakan kapal laut yang mengarungi samudera; (f) Pengangkutan udara (transportation by air atau air transportation), yaitu pengangkutan dengan menggunakan kapal terbang yang melalui jalan udara.

12 Abdulkadir Muhammad, Hukum Pengangkutan Niaga, (Bandung: Penerbit Citra Aditya Bhakti, 1998), h. 12.

13 Ibid, h. 13.

${ }^{14}$ Rustian Kamaludin, Ekonomi Transportasi, (Padang: Ghalia Indonesia, 1986), h.15-19. 
Di dalam hukum pengangkutan juga terdapat asas-asas hukum, yang terbagi ke dalam dua jenis, yaitu bersifat publik dan bersifat perdata. ${ }^{15}$ Asas yang bersifat publik merupakan landasan hukum pengangkutan yang berlaku dan berguna bagi semua pihak, yaitu pihak-pihak dalam pengangkutan, pihak ketiga yang berkepentingan dengan pengangkutan, dan pihak pemerintah. Asas-asas yang bersifat publik biasanya terdapat di dalam penjelasan undang-undang yang mengatur tentang pengangkutan, sedangkan asas-asas yang bersifat perdata merupakan landasan hukum pengangkutan yang hanya berlaku dan berguna bagi kedua pihak dalam pengangkutan niaga, yaitu pengangkut dan penumpang atau pengirim barang. ${ }^{16}$ Asas-asas hukum pengangkutan bersifat publik meliputi : asas manfaat, asas usaha bersama dan kekeluargaan, asas adil dan merata, asas keseimbangan, asas kepentingan umum, asas keterpaduan, asas kesadaran hukum, asas percaya pada diri sendiri, dan asas keselamatan penumpang. Sedangkan asas-asas hukum pengangkutan bersifat perdata meliputi : asas konsensual, asas koordinatif, asas campuran, asas retensi, asas pembuktian dengan dokumen.

Dalam UUPK yang dimaksud konsumen adalah setiap orang pemakai barang dan/atau jasa yang tersedia dalam masyarakat, baik bagi kepentingan diri sendiri, keluarga, orang lain, maupun makhluk hidup lain dan tidak untuk diperdagangkan. ${ }^{17}$ Dalam rumusan ini ditentukan batasan secara jelas limitatif tentang konsumen, yaitu merupakan orang, memakai atau menggunakan suatu barang dan/jasa, untuk kepentingan sendiri maupun untuk kepentingan orang lain atau makhluk lain, dan tidak untuk diperdagangkan kembali. Dalam ilmu ekonomi pengertian di atas termasuk dalam kategori konsumen akhir. Pengertian konsumen di atas kurang tepat dan adanya kerancuan, yaitu pada kata pemakai yang tidak sesuai atau tidak berhubungan dengan kalimat untuk kepentingan pihak lain, serta rumusannya hanya terpaku pada orang atau makhluk lain, padahal dalam kenyataan tidak hanya orang saja yang disebut konsumen, tetapi masih ada yang lain, yakni badan usaha. ${ }^{18}$ Dalam kaitan dengan penelitian ini juga terdapat pengertian pengguna jasa dalam UULLAJ yaitu perseorangan atau badan hukum yang menggunakan jasa perusahaan angkutan umum (Pasal 1 angka (22)). Definisi ini lebih sempit pengertiannya dibandingkan dengan definisi yang terdapat dalam Pasal 1 angka (10) UULLAJ 1992, yaitu: "pengguna jasa adalah setiap orang dan/atau badan hukum yang menggunakan jasa angkutan, baik untuk angkutan orang maupun untuk

15 Abdulkadir Muhammad, Hukum Pengangkutan Niaga, (Bandung: Penerbit Citra Aditya Bhakti, 1998), h. 17.

${ }^{16} \mathrm{Ibid}$,

17 Pasal 1 angka (2), Undang-Undang No.8 Tahun 1999 tentang Perlindungan Konsumen, Lembaran Negara Republik Indonesia Tahun 1999 Nomor 42, Tambahan Lembaran Negara Nomor 3821.

18 Ahmadi Miru dan Sutarman Yudo, Hukum Perlindungan Konsumen, (Jakarta: PT. RajaGrafindo Persada, 2005), h. 4. 
barang". ${ }^{19}$ Berdasarkan kedua pengertian diatas menunjukkan bahwa pengertian konsumen dan pengguna jasa memiliki substansi yang berkaitan yaitu orang yang menggunakan jasa yang dalam hal ini adalah jasa angkutan umum jenis angkot. Namun demikian, pengertian tersebut agaknya memiliki disparitas dari sisi definisi operasional, mengingat bahwa yang dimaksud konsumen dalam UUPK adalah yang menggunakan barang dan/atau jasa yang tersedia dalam masyarakat. Lain halnya dengan pengertian pengguna jasa dalam UULLAJ yang lebih sempit pengertiannya dibandingkan dengan definisi konsumen dalam UUPK. Dalam UULLAJ tersebut mengharuskan adanya penggunaan jasa perusahaan angkutan umum, sementara perusahaan angkutan umum yang dimaksud dalam UULLAJ tersebut adalah yang berbadan hukum.

Disamping pengertian konsumen diatas juga terdapat pengertian pelaku usaha dalam Pasal 1 angka 3 UU No. 8 tahun 1999 tentang Perlindungan Konsumen dibatasi sebagai setiap orang perseorangan atau badan usaha, baik yang berbentuk badan hukum maupun bukan badan hukum yang didirikan dan berkedudukan atau melakukan kegiatan dalam wilayah hukum negara Republik Indonesia, baik sendiri maupun bersama-sama melalui perjanjian menyelenggarakan kegiatan usaha dalam berbagai bidang ekonomi. Sementara itu, dalam pengertian UULLAJ bahwa Perusahaan angkutan umum adalah badan hukum yang menyediakan jasa angkutan orang dan/atau barang dengan kendaraan bermotor umum (Pasal 1 angka 21). Menurut ketentuan angka 21 ini, bentuk usaha perusahaan angkutan umum ditegaskan harus berbentuk badan hukum, yaitu harus berbentuk Perseroan Terbatas (PT); Badan Usaha Milik Negara (BUMN) dan Koperasi, sedangkan yang bukan badan hukum, seperti Perusahaan Perorangan, Persekutuan Perdata, Firma maupun Commanditaire Venootschap $(\mathrm{CV})$ tidak boleh menyediakan angkutan umum. Hal ini berbeda dengan dengan ketentuan lama UULLAJ 1992, yang tidak mengharuskan badan hukum yang menyediakan jasa angkutan umum, sebagaimana ditentukan dalam Pasal 1 angka (8): "Perusahaan Angkutan Umum adalah perusahaan yang menyediakan jasa angkutan orang dan/atau barang dengan kendaraan umum" ${ }^{20}$ Apabila dikomparasikan berdasarkan UULLAJ 2009 dan UUPK bahwa dalam UULLAJ 2009 tersebut tidak mengenal istilah pelaku usaha, akan tetapi yang dikenal adalah perusahaan angkutan umum. Dari kedua pengertian tersebut menunjukkan bahwa terdapat disparitas pengertian pelaku usaha dengan pengertian perusahaan angkutan umum. Namun demikian, apabila dilihat pengertian pelaku usaha dalam UUPK maka pengertian perusahaan angkutan

19 Pasal 1 angka (10), Undang-Undang Nomor 14 Tahun 1992 Tentang Lalu Lintas dan Angkutan Jalan, Lembaran Negara Republik Indonesia Tahun 1992 Nomor 49, Tambahan Lembaran Negara Nomor 3480.

${ }^{20}$ Ibid, Pasal 1 angka (8). 
umum tersebut termasuk kategori pelaku usaha. Pengertian pelaku usaha dalam UUPK tidak mengharuskan pelaku usaha itu berbadan hukum. ${ }^{21}$

Berdasarkan Pasal 4 UUPK disebutkan bahwa konsumen memiliki hak diantaranya adalah : Hak atas kenyamanan, keamanan, dan keselamatan dalam mengkonsumsi barang dan/atau jasa, Hak untuk memilih barang dan/atau jasa, Hak untuk mendapatkan informasi yang benar, jelas, dan jujur mengenai kondisi dan jaminan barang dan/atau jasa, Hak untuk didengar pendapat dan keluhannya, Hak untuk mendapatkan bantuan hukum (advokasi), perlindungan dan penyelesaian sengketa perlindungan konsumen secara patut, Hak untuk memperoleh pembinaan dan pendidikan konsumen, Hak untuk diperlakukan atau dilayani secara benar, jujur, dan tidak diskriminatif, Hak untuk mendapatkan kompensasi, ganti rugi, dan/atau penggantian apabila barang dan/atau jasa yang diterima tidak sesuai dengan perjanjian atau tidak sebagaimana mestinya, dan Hak-hak yang ditentukan dalam perundangundangan lainnya. ${ }^{22}$ Di sisi lain dalam Pasal 5 UUPK juga mengatur mengenai kewajiban konsumen diantaranya : Membaca atau mengikuti petunjuk informasi dan prosedur atau pemanfaatan barang dan/atau jasa, demi keamanan dan keselamatan, Beritikad baik dalam melakukan transaksi pembelian barang dan/atau jasa, Membayar sesuai dengan nilai tukar yang disepakati, dan Mengikuti upaya penyelesaian hukum sengketa perlindungan konsumen secara patut. $^{23}$

Pengaturan mengenai hak pelaku usaha juga diatur dalam Pasal 6 UUPK, diantaranya: Hak untuk menerima pembayaran yang sesuai dengan kesepakatan mengenai kondisi dan nilai tukar barang dan/atau jasa yang diperdagangkan; Hak untuk mendapatkan perlindungan hukum dari tindakan hukum yang beritikad tidak baik; Hak untuk melakukan pembelaan diri sepatutnya di dalam penyelesaian hukum sengketa konsumen; Hak untuk rehabilitasi nama baik apabila tidak terbukti secara hukum bahwa kerugian konsumen tidak diakibatkan oleh barang dan/atau jasa yang diperdagangkan; dan Hak-hak yang diatur dalam ketentuan peraturan perundang-undangan lainnya. ${ }^{24}$ Sedangkan Berdasarkan Pasal 7 UUPK, Kewajiban Pelaku Usaha adalah : Beritikad Baik dalam menjalankan kegiatan usahanya;Memberikan informasi yang benar, jelas, dan jujur mengenai jaminan barang dan/atau jasa, serta memberikan penjelasan penggunaan, perbaikan, dan pemeliharaan; Memperlakukan atau melayani konsumen secara benar dan jujur, secara tidak diskriminatif; Menjamin mutu

${ }^{21}$ Lihat Pasal 1 angka (3), Undang-Undang No. 8 Tahun 1999 tentang Perlindungan Konsumen, Lembaran Negara Republik Indonesia Tahun 1999 Nomor 42, Tambahan Lembaran Negara Nomor 3821.

${ }_{22}$ Pasal 4, Undang-Undang No.8 Tahun 1999 tentang Perlindungan Konsumen, Lembaran Negara Republik Indonesia Tahun 1999 Nomor 42, Tambahan Lembaran Negara Nomor 3821.

${ }^{23}$ Ibid, Pasal 5.

${ }^{24}$ Ibid, Pasal 6. 
barang dan/atau jasa yang diproduksi dan/atau diperdagangkan berdasarkan ketentuan standar mutu dan/atau jasa yang berlaku; Memberikan kesempatan kepada konsumen untuk menguji dan/atau mencoba barang dan/atau jasa tertentu serta memberikan jaminan dan/atau garansi barang yang dibuat dan/atau diperdagangkan; Memberi kompensasi, ganti rugi, dan/atau penggantian atas kerugian akibat penggunaan, pemakaian, dan pemanfaatan barang dan/atau jasa yang diperdagangkan; dan Memberi kompensasi, ganti rugi dan/atau penggantian apabila barang dan/atau jasa yang diterima atau dimanfaatkan tidak sesuai dengan perjanjian. ${ }^{25}$

\section{Hak Konsumen Pengguna Jasa Angkutan Umum Jenis Angkot Terkait Dengan Standar Pelayanan Minimal (SPM)}

Jakarta sebagai ibukota Indonesia memiliki tingkat perekonomian yang lebih baik dibandingkan dengan kota-kota lain. Perkembangan Jakarta dan daerah sekitarnya dapat dikatakan sebagai monometric pattern yang menempatkan Jakarta sebagai pusat ekonomi dan bisnis. Sebagian besar warga Jakarta bertempat tinggal di luar kota atau daerah penyangga yang memerlukan sekitar 1-2 jam waktu tempuh untuk mencapai pusat ekonomi dan bisnis. Kondisi ini adalah salah satu penyebab kemacetan di Jakarta. ${ }^{26}$ Pada awal 1970an pemakai kendaraan umum jumlahnya sebesar $70 \%$ dari total pemakai kendaraan di jalan. Angka ini mengalami penurunan yang cukup tajam yaitu sebesar 57 \% di tahun 1985 dan hanya $45 \%$ di tahun 2000. Penurunan minat pengguna kendaraan umum disebabkan oleh banyak faktor, salah satunya karena terjadinya motorisasi besar-besaran, bahkan lebih tinggi dibandingkan sebelum krisis terjadi, yaitu meningkat sekitar $16-18 \%$ per tahun. Sekitar 5 juta kendaraan bertambah setiap tahun, dan tahun 2007 diperkirakan sekitar 35 juta populasi kendaraan. Kondisi lain yang menurunkan minat masyarakat untuk menggunakan kendaraan umum adalah ketidaknyamanan sarana transportasi, baik dari alat transportasi yang kurang pemeliharaan maupun gangguan keamanan. ${ }^{27}$

Perjalanan sejarah transportasi angkutan umum di Indonesia sendiri pada dasarnya dikelompokkan dalam 5 generasi. Generasi pertama terjadi saat pemerintah menghentikan pengoperasian tram pada tahun 1970-an di beberapa kota di Indonesia, lalu muncul kendaraan kecil seperti oplet. Tahun 1985 adalah generasi kedua dengan munculnya PPD. Saat itu terdapat kurang lebih 5 perusahaan bus besar. Pada era ini pula terjadi penggabungan atau merger dan restrukturisasi dalam pengelolaan transportasi bus di Indonesia. Tahun 1987

\footnotetext{
${ }^{25}$ Ibid, Pasal 7.

${ }^{26}$ Artikel dari Majalah Inovasi, Volume 10/XX/Maret 2008, "Reformasi Transportasi Publik di Jakarta: Sebuah Kisah Sukses", h. 14.

${ }^{27} \mathrm{Ibid}$,
} 
adalah generasi ketiga yaitu dikembangkannya bus-bus besar seperti bus tingkat di beberapa kota di Indonesia. Tahun 1992, generasi keempat, yaitu lajur bus yang diprioritaskan di sebelah kiri, namun sistem ini pun tidak berjalan dengan baik. Generasi kelima adalah pengoperasian busway. Transportasi busway di Indonesia dikembangkan berdasarkan analisis faktor-faktor yang menyebabkan buruknya pengelolaan angkutan umum di Indonesia selama ini. ${ }^{28}$

Jenis angkutan umum perkotaan di Jakarta yang berjenis "angkot" menurut Tulus Abadi. ${ }^{29}$ Pada awalnya angkutan umum perkotaan itu disingkat angkot. Adapun klasifikasinya terdiri dari bus besar, bus sedang, dan bus kecil. Namun, dalam perkembangannya di masyarakat pengertian "angkot" itu mengalami bias makna menjadi Angkutan Kota jenis Bus Kecil (Micro Bus) yang fungsinya merupakan angkutan pengumpan. Untuk lebih jelasnya, diuraikan berdasarkan data statistik yang penulis peroleh dari data Dinas Perhubungan Pemerintah Provinsi DKI Jakarta. Lihat dalam Tabel 1.1. Angkutan Penumpang dan Barang. ${ }^{30}$

\begin{tabular}{|c|c|c|c|c|c|c|}
\hline \multirow{2}{*}{ NO } & \multirow{2}{*}{ JENIS KENDARAAN } & \multicolumn{5}{|c|}{ TAHUN } \\
\hline & & 2008 & 2009 & 2010 & 2011 & 2012 \\
\hline 1 & Bus Besar *) & 4.822 & 4.928 & 4.579 & 3.529 & 2.045 \\
\hline 2 & Bus Sedang & 4.960 & 4.960 & 4.944 & 4.959 & 1.987 \\
\hline 3 & Bus Kecil /Angkot & 12.984 & 14.130 & 14.183 & 14.183 & 16.671 \\
\hline 4 & Bajaj \& Kancil & 14.424 & 14.424 & 14.424 & 14.424 & 14.424 \\
\hline 5 & Taksi & 24.256 & 24.489 & 24.724 & 24.902 & 27.301 \\
\hline 6 & Bus Wisata \& Sewa & 5.219 & 5.048 & 4.707 & 4.416 & 5.091 \\
\hline 7 & Bus Antar Kota & 3.587 & 3.463 & 3.279 & 3.279 & 3.442 \\
\hline \multicolumn{2}{|c|}{$\begin{array}{l}\text { JUMLAH ANGKUTAN } \\
\text { PENUMPANG }\end{array}$} & 70.252 & 71.442 & 70.840 & 69.692 & 70.961 \\
\hline 8 & Mobil Barang & 18.157 & 20.013 & 19.138 & 23.649 & 36.332 \\
\hline \multicolumn{2}{|r|}{ JUMLAH TOTAL } & 88.409 & 91.455 & 89.978 & 93.341 & 107.293 \\
\hline \multicolumn{2}{|c|}{$\begin{array}{l}\text { Keterangan : } \\
\left.{ }^{*}\right) \text { Termasuk Busway }\end{array}$} & & & & & \\
\hline
\end{tabular}

Berdasarkan data yang penulis dapatkan dari Dinas Perhubungan Provinsi DKI Jakarta, bahwa terdapat total 6.293 armada angkutan umum jenis kendaraan mikrolet dengan rincian yang terdiri dari 15 perusahaan angkutan umum angkot jenis kendaraan mikrolet yang berbadan hukum. Adapun klasifikasinya terdiri dari: 9 (sembilan) perusahaan yang berbentuk Perseroan Terbatas (PT) dan 6 (enam) perusahaan yang berbentuk koperasi. Disamping klasifikasi tersebut juga terdapat Mikrolet yang dimiliki oleh perorangan dengan

\footnotetext{
${ }^{28}$ Ibid, h. $15-16$

${ }_{29}$ Wawancara dengan Bapak Tulus Abadi (Pengurus Harian YLKI dan Anggota Dewan
} Transportasi Kota Jakarta) di Jakarta pada 12 April 2013.

${ }^{30}$ Dinas Perhubungan Provinsi DKI Jakarta 
jumlah 386 armada. Sehingga apabila dijumlah secara keseluruhan angkutan umum (angkot) dengan jenis kendaraan mikrolet berjumlah 6.679 armada.

Pengaturan mengenai perlindungan hak-hak konsumen dalam hal jasa layanan angkutan umum tercantum di dalam Undang-Undang No. 22 Tahun 2009 tentang lalu Lintas dan Angkutan Jalan (UULLAJ). Dalam undangundang tersebut, hak konsumen dijamin melalui adanya pengaturan kewajibankewajiban yang harus dilakukan oleh pelaku usaha jasa angkutan umum dalam menyelenggarakan kegiatan usahanya. Secara umum kewajiban itu tercantum dalam Pasal 141 UULLAJ, bahwa perusahaan angkutan umum wajib memenuhi standar pelayanan minimal yang meliputi : a) keamanan, b) keselamatan, c) kenyamanan, d) keterjangakauan, e) kesetaraan, dan f) keteraturan. ${ }^{31}$ Disamping itu juga diatur kriteria angkutan dalam trayek ini harus memiliki rute tetap dan teratur, terjadwal, berawal, berakhir, dan menaikkan atau menurunkan penumpang di terminal untuk angkutan antarkota dan lintas batas negara serta menaikkan dan menurunkan penumpang pada tempat yang ditentukan untuk angkutan perkotaan dan pedesaan (Pasal 143). Perusahaan Angkutan Umum Wajib: (1) Mengangkut orang dan/atau barang setelah disepakati perjanjian pengangkutan dan/atau dilakukan pembayaran biaya angkutan oleh penumpang dan/atau pengirim barang (pasal 186); (2) Mengembalikan biaya angkutan yang telah dibayar oleh penumpang dan/atau pengirim barang jika terjadi pembatalan pemberangkatan (Pasal 187); (3) Mengganti kerugian yang diderita oleh penumpang dan/atau pengirim barang karena lalai dalam melaksanakan pelayanan angkutan (Pasal 188); (4) Mengasuransikan tanggung jawabnya sebagaimana dimaksud dalam Pasal 188.

Berkaitan dengan peraturan dalam UULLAJ tersebut juga terdapat peraturan teknis yang mengatur mengenai standar pelayanan minimal yaitu (1) Peraturan Menteri Perhubungan Nomor 81 Tahun 2011 Tentang Standar Pelayanan Minimal Bidang Perhubungan Daerah Provinsi dan Daerah Kabupaten/Kota yang terdiri atas jenis pelayanan, indikator kinerja, dan target tahun 2010 - tahun 2014. Terhadap jenis pelayanan tersebut, Pemerintah Daerah Provinsi dan Pemerintah Daerah Kabupaten/Kota tertentu wajib menyelenggarakan jenis pelayanan sesuai kebutuhan, karakteristik dan potensi daerah. (2) Peraturan Menteri Perhubungan Nomor 10 Tahun 2012 Tentang Standar Pelayanan Minimal Angkutan Massal Berbasis Jalan Jenis Pelayanan, yang meliputi (Keamanan, Keselamatan, Kenyamanan, Keterjangakuan, Kesetaraan, dan Keteraturan). Mutu Pelayanan, yang meliputi (indikator, dan nilai, ukuran, atau jumlah). Sedangkan dalam kaitannya dengan otonomi daerah, pengaturan mengenai standar pelayanan minimal juga diatur dalam Peraturan

${ }^{31}$ Pasal 141 ayat (1), Undang-Undang Nomor 22 Tahun 2009 tentang Lalu Lintas dan Angkutan Jalan, Lembaran Negara Republik Indonesia Tahun 2009 Nomor 96, Tambahan Lembaran Negara Nomor 5025. 
Daerah No. 12 Tahun 2003 tentang Lalu Lintas dan Angkutan Jalan, Kereta Api, Sungai, dan Danau serta Penyeberangan di Provinsi DKI Jakarta yang mana didalamnya tidak mengatur secara spesifik melainkan secara tersirat. Ketentuan tersebut dapat dipahami melalui beberapa ketentuan yang mengatur mengenai sarana, prasarana, dan pengemudi angkutan jalan.

\section{Upaya Perlindungan Hukum Bagi Konsumen Sebagai Pengguna Jasa Angkutan Umum Jenis Angkot di Jakarta}

Ada beberapa kasus-kasus kejahatan yang terjadi dalam angkutan umum jenis angkot yang sudah inkracht dalam putusan pengadilan, diantaranya: a). Putusan Pengadilan Negeri Jakarta Pusat Nomor 1687/PID.B/2012/PN.JKT.PST. ; b). Putusan Pengadilan Negeri Jakarta Barat Nomor 2626/Pid.B/2011/PN.JKT.BAR; c). Putusan Pengadilan Negeri Jakarta Selatan Nomor 1563/Pid.B/2011/PN.Jkt.Sel; d). Putusan Pengadilan Negeri Jakarta Selatan Nomor 1560/PID.B/2011/PN.Jkt.Sel; dan e). Putusan Pengadilan Negeri Jakarta Selatan Nomor 1561/Pid.B/2011/PN.Jkt.Sel.

Menurut penulis bahwa semua pemilik angkutan umum dalam semua kasus diatas termasuk kategori pelaku usaha yang bertanggung jawab penuh atas kerugian yang diderita pengguna jasa, penumpang maupun pihak ke-3 yang timbul dari penyelenggaraan pelayanan angkutannya. Tanggung jawab atas kerugian yang diderita penumpang sebagai konsumen pengguna jasa transportasi ataupun pihak lain muncul karena pengangkut atau pihak yang menyediakan fasilitas angkutan umum bertanggung jawab untuk melaksanakan kegiatan tersebut dengan sebaik-baiknya. Karena itu, pengangkut dalam melaksanakan kewajibannya tidak boleh lalai. Hal mengenai pertanggungjawaban tersebut tercantum dalam Pasal 188 Undang-Undang Nomor 22 Tahun 2009 tentang lalu lintas dan angkutan jalan yang menyatakan bahwa Perusahaan Angkutan Umum wajib mengganti kerugian yang di derita oleh penumpang atau pengirim barang karena lalai dalam melaksanakan pelayanan angkutan. ${ }^{32}$ Disamping itu juga, mengingat betapa pentingnya tanggung jawab perusahaan angkutan umum yang didelegasikan melalui orang yang dipekerjakannya yaitu pengemudi/supir angkot, maka berdasarkan Pasal 191 UULLAJ bahwa perusahaan angkutan umum bertanggung jawab atas kerugian yang diakibatkan oleh segala perbuatan orang yang dipekerjakan dalam kegiatan penyelenggaraan angkutan. ${ }^{33}$

Berkaitan dengan tanggung jawab itu, dalam Undang-Undang No. 8 Tahun 1999 tentang Perlindungan Konsumen sendiri diatur pada Pasal 19 ayat (1), yang menyatakan bahwa pelaku usaha bertanggung jawab memberikan

32 Ibid, Pasal 188.

${ }^{33}$ Ibid, Pasal 191. 
ganti rugi atas kerusakan, pencemaran, dan/atau kerugian konsumen akibat mengkonsumsi barang dan/atau jasa yang dihasilkan atau diperdagangkan. ${ }^{34} \mathrm{Hal}$ tersebut sejalan dengan apa yang diatur dalam Pasal Pasal 188 dan Pasal 191 Undang-Undang Nomor 22 Tahun 2009 tentang lalu lintas dan angkutan jalan. Bentuk tanggung jawab pengangkut sebagaimana diatur dalam dua aturan hukum di atas sebenarnya merupakan hal yang wajar sebab hal ini merupakan kompensasi pemenuhan hak konsumen yang tidak dapat dipenuhi oleh pelaku usaha angkutan umum jenis angkot. Hak konsumen dimaksud adalah hak seperti yang terdapat dalam Pasal 4 huruf a, d, dan $\mathrm{h}^{35}$ Undang-Undang No.8 Tahun 1999 tentang Perlindungan Konsumen, yaitu hak atas keamanan, kenyamanan, dan keselamatan; hak didengar pendapat dan keluhannya; hak mendapat ganti rugi. Hak konsumen tersebut sekaligus menjadi kewajiban bagi pelaku usaha sebagaimana yang tercantum dalam Pasal 7 huruf a dan $\mathrm{f}^{36}$ Undang-Undang No. 8 Tahun 1999 tentang Perlindungan Konsumen, yaitu kewajiban untuk beritikad baik dalam melakukan kegiatan usahanya dan kewajiban untuk memberi kompensasi atau ganti rugi. Namun, tidak sepenuhnya juga bahwa setiap kerugian yang dialami penumpang atau pihak ke-3 mutlak dan selalu menjadi tanggung jawab pelaku usaha sebagai pengangkut penumpang. Sepanjang kerugian tersebut terbukti memang merupakan kesalahan pelaku usaha angkutan umum jenis angkot maka pelaku usaha angkutan umum jenis angkot wajib bertanggung jawab.

Jika kerugian tersebut disebabkan kesalahan, kecerobohan, atau kelalaian penumpang atau pihak ke-3 sendiri, berdasarkan Pasal 19 ayat (5) ${ }^{37}$ UndangUndang No. 8 Tahun 1999 tentang Perlindungan Konsumen, pelaku usaha angkutan umum jenis angkot tidak harus bertanggung jawab, artinya pengangkut tidak harus memberi kompensasi atau ganti rugi pada penumpang atau pihak ke-3 tersebut. Karena itu, tuntutan ganti rugi yang diajukan oleh penumpang atau pihak ke-3 hanya dapat dilakukan dan didasari oleh sebabsebab yang terkait atau disebabkan oleh pengangkut sendiri atau pegawainya atau hal-hal lain yang berhubungan dengan pengangkut. ${ }^{38}$

Berkaitan dengan tanggung jawab perusahaan angkutan umum terhadap penumpang yang diatur dalam Pasal 192 ayat (1), yaitu: Perusahaan angkutan umum bertanggung jawab atas kerugian yang diderita oleh penumpang yang meninggal dunia atau luka akibat penyelenggaraan angkutan kecuali disebabkan

34 Pasal 19 ayat (1), Undang-Undang No. 8 Tahun 1999 tentang Perlindungan Konsumen, Lembaran Negara Republik Indonesia Tahun 1999 Nomor 42, Tambahan Lembaran Negara Nomor 3821.

${ }^{35}$ Ibid, Pasal 4 huruf a, d, dan h.

${ }^{36} \mathrm{Ibid}$, Pasal 7 huruf a dan $\mathrm{f}$.

${ }^{37}$ Ibid, Pasal 19 Ayat (5)

38 Benadetta T. Wulandari, Busway vs Kemacetan: Tinjauan Atas Hak Konsumen, dalam Jurnal, Lembaga Penelitian dan Pengabdian Kepada Masyarakat, Fakultas Hukum Universitas Katolik Atmajaya, Jakarta), hlm. 8. 
oleh suatu kejadian yang tidak dapat dicegah atau dihindari atau karena kesalahan penumpang. ${ }^{39}$ Berdasarkan ketentuan ayat tersebut ada 4 (empat) hal yang sekaligus diatur, yaitu : (1) Tanggung jawab perusahaan angkutan umum untuk mengganti kerugian; (2) Ganti kerugian tersebut diberikan kepada penumpang yang meninggal dunia atau luka-luka; (3) Kerugian terjadi akibat penyelenggaraan angkutan; (4) Dikaitkan dengan teori prinsip-prinsip tanggung jawab di bidang angkutan, maka sistem tanggung jawab yang dianut adalah Presumtion of Liability. Hal ini dapat diketahui dari kalimat ..."kecuali terbukti oleh suatu kejadian yang tidak dapat dicegah atau dihindari atau karena kesalahan penumpang". Berdasarkan sistem tanggung jawab Presumtion of Liability, Perusahaan angkutan umumlah yang harus membuktikan adanya kerugian yang diderita penumpang, sehingga menyebabkan penumpang meninggal atau luka. Akan tetapi, dalam sistem ini, perusahaan angkutan dapat membebaskan diri dari tanggung jawabnya untuk membayar ganti kerugian, jika perusahaan angkutan dapat membuktikan salah satu dari dua hal, yaitu: (a) Disebabkan oleh suatu kejadian yang tidak dapat dicegah atau dihindari atau overmacht atau force majeure; atau (b) karena kesalahan penumpang sendiri. Sementara limit atau batas jumlah ganti kerugian yang harus dibayarkan oleh perusahaan angkutan kepada penumpang yang meninggal dunia atau luka-luka, ditentukan dalam Pasal 192 ayat (2), yaitu dihitung berdasarkan kerugian yang nyata-nyata dialami atau bagian biaya perawatan. Ayat ini mengatur sistem Limitation of Liability atau besarnya jumlah ganti kerugian, yang harus diberikan oleh perusahaan angkutan kepada penumpang yang meninggal dunia atau mengalami luka-luka. Sayang sekali di dalam penjelasan ayatnya, tidak dijelaskan pengertian kerugian yang secara nyata dialami, selain itu juga tidak diatur mengenai perhitungan kerugian bagi penumpang yang mengalami cacat tetap..$^{40}$ Ayat ini masih mempunyai kelemahan, karena perhitungan "berdasarkan kerugian yang nyata-nyata dialami" itu, menurut penulis ditujukan kepada penumpang yang meninggal dunia. Seharusnya ganti kerugian yang dihitung berdasarkan kerugian yang nyata-nyata dialami, tidak dapat diterapkan kepada penumpang yang meninggal dunia, karena jiwa seseorang tidak dapat dinilai dengan uang, sehingga tidak dapat dihitung kerugiannya. Sedangkan bagi penumpang yang mengalami luka-luka, perhitungannya didasarkan pada bagian biaya perawatan.

Berdasarkan wawancara penulis dengan Bapak Baihaqi selaku Kepala Seksi Angkutan Orang Dalam Trayek Dinas Perhubungan Pemerintah Provinsi DKI Jakarta pada 14 Juni 2013 bahwa terhadap kasus-kasus tersebut diatas,

${ }^{39}$ Pasal 192 ayat (1), Undang-Undang Nomor 22 Tahun 2009 tentang Lalu Lintas dan Angkutan Jalan, Lembaran Negara Republik Indonesia Tahun 2009 Nomor 96, Tambahan Lembaran Negara Nomor 5025.

40 Siti Nurbaiti, Hukum Pengangkutan Darat : Jalan dan Kereta Api, (Jakarta: Penerbit Universitas Trisakti, 2009), hlm. 98. 
semuanya dikenakan sanksi pidana yang sesuai dengan tindak pidana yang dilakukan oleh pelakunya. Pengenaan sanksi pidana tersebut semata-mata hanya didasarkan pada aspek penegakan hukum pidana saja. Adapun pengenaan sanksi pidana yang didasarkan atas undang-undang perlindungan konsumen belum diterapkan. Hal tersebut, dapat terlihat dari putusan hakim yang menunjukkan bahwa hakim belum mempertimbangkan mengenai tanggung jawab pelaku usaha angkot dari sisi kerugian konsumen sebagai pengguna jasa maupun penumpang angkutan umum karena dalam dakwaan dan tuntutannya Jaksa Penuntut Umum tidak mempertimbangkan mengenai tanggung jawab pelaku usaha sebagaimana diatur dalam undang-undang perlindungan konsumen.

Namun demikian, hal tersebut tidak menutup kemungkinan adanya sanksi administratif yang diatur dalam Pasal 199 ayat (1) UULLAJ yang menyatakan bahwa pelanggaran terhadap ketentuan sebagaimana diatur dalam Pasal 167, Pasal 168, Pasal 173, Pasal 177, Pasal 186, Pasal 187, Pasal 189, Pasal 192, dan Pasal 193 dikenai sanksi administratif berupa: (a) peringatan tertulis; (b) denda administratif; (c) pembekuan izin; dan (d) pencabutan izin. ${ }^{41}$ Oleh karena itu, terhadap kasus-kasus tersebut diatas semuanya telah dikenakan sanksi administratif berupa Pembekuan Izin. ${ }^{42}$

Adapun upaya hukum yang dapat dilakukan konsumen terkait dengan kerugian yang dialami sebagai pengguna jasa angkutan umum jenis angkot di Jakarta yaitu: Penyelesaian Sengketa di luar Pengadilan, yang diatur pada Pasal 47 UUPK; Penyelesaian Melalui Badan Penyelesaian Sengketa Konsumen (BPSK); Penyelesaian Sengketa Konsumen Melalui Lembaga Perlindungan Konsumen Swadaya Masyarakat (LPKSM); Penyelesaian Sengketa Konsumen Melalui Pengadilan. Dalam Pasal 48 UUPK menyatakan Penyelesaian sengketa konsumen melalui pengadilan mengacu pada ketentuan tentang peradilan umum yang berlaku dengan memperhatikan ketentuan dalam Pasal 45.

Namun yang sangat disayangkan bahwa selama ini belum pernah ada pengguna jasa maupun penumpang yang melakukan gugatan terhadap perusahaan angkutan umum jenis angkot. Padahal konsumen menyadari bahwa angkutan umum jenis angkutan kota atau angkot yang ada di Jakarta ini, belum memadai dan belum memberikan perlindungan terhadap konsumennya. Secara sederhana hal tersebut dapat dipahami bahwa dari posisi tawar (bargaining power) konsumen masih sangat lemah. Sehingga belum ada konsumen yang menggugat pelaku usaha karena kerugiannya dalam menggunakan angkutan umum. Kecuali untuk hal-hal yang sifatnya kejahatan atau kriminal. Itupun dari

${ }^{41}$ Pasal 199 Ayat (1), Undang-Undang Nomor 22 Tahun 2009 tentang Lalu Lintas dan Angkutan Jalan, Lembaran Negara Republik Indonesia Tahun 2009 Nomor 96, Tambahan Lembaran Negara Nomor 5025.

42 Wawancara dengan Bapak Baihaqi, Selaku Kepala Seksi Angkutan Orang Dalam Trayek Dinas Perhubungan Provinsi DKI Jakarta pada 14 Juni 2013 
beberapa kasus yang kami uraikan diatas, tidak satu pun amar putusan hakim yang memerintahkan untuk menghukum pelaku usaha untuk bertanggung jawab terhadap konsumen yang mengalami kerugian dalam menggunakan jasa angkutannya. Sehingga tidak ada sama sekali yang namanya ganti kerugian oleh pelaku usaha atau perusahaan angkutan umum terhadap konsumen maupun pengguna jasanya.

\section{Kesimpulan}

Pengaturan bentuk jaminan perlindungan hukum bagi konsumen sebagai pengguna jasa maupun penumpang angkutan umum diatur dalam hukum pengangkutan penumpang yang diatur dalam Kitab Undang-Undang Hukum Dagang Buku II Bab V B Pasal 521 sampai Pasal 544a Tentang Pengangkutan Orang. Disamping pengaturan umum tersebut, bentuk perlindungan hukum bagi konsumen pengguna jasa maupun penumpang angkutan umum juga diatur secara spesifik dalam Peraturan perundang-undangan khusus seperti undangundang nomor 8 tahun 1999 tentang perlindungan konsumen dan undangundang nomor 22 tahun 2009 tentang lalu lintas dan angkutan jalan.

Standar pelayanan minimal angkutan umum jenis angkot dalam rangka pemenuhan hak konsumen sebagai pengguna jasa maupun penumpang angkutan umum jenis angkot di Jakarta secara umum diatur berdasarkan undang-undang nomor 22 tahun 2009 tentang lalu lintas dan angkutan jalan dengan ketentuan standar pelayanan minimal yang meliputi keamanan, keselamatan, kenyamanan, keterjangkauan, kesetaraan, dan keteraturan. Dengan rincian penjelasannya yang diatur dalam Peraturan Menteri Perhubungan Nomor 81 Tahun 2011 Tentang Standar Pelayanan Minimal Bidang Perhubungan Daerah Provinsi dan Daerah Kabupaten/Kota yang meliputi: jaringan pelayanan angkutan jalan, jaringan prasarana angkutan jalan, fasilitas perlengkapan jalan, keselamatan, dan sumber daya manusia (SDM) untuk daerah Provinsi dan untuk daerah Kabupaten/Kota ditambah dengan fasilitas pelayanan pengujian kendaraan bermotor. Disamping peraturan menteri perhubungan tersebut, standar pelayanan minimal juga diatur secara tersirat dalam Peraturan Daerah DKI Jakarta Nomor 12 Tahun 2003 Tentang Lalu Lintas dan Angkutan Jalan, Kereta Api, Sungai, dan Danau Serta Penyeberangan di Provinsi Daerah Khusus Ibukota Jakarta dengan ketentuan bahwa setiap kendaraan umum dalam trayek wajib menaikkan dan/atau menurunkan penumpang di tempat pemberhentian berupa bangunan halte atau tempat pemberhentian kendaraan umum yang dinyatakan dengan rambu, serta ditetapkan batas umur kendaraan angkutan umum. Dan juga ditetapkan prosentase penembusan cahaya pada kaca-kaca kendaraan bermotor, juga mengenai kewajiban pengemudi dalam mengemudikan kendaraan angkutan umum. 
Upaya yang dapat dilakukan konsumen yang mengalami kerugian dalam pelayanan angkutan umum jenis angkot di Jakarta ini, terdapat beberapa alternatif penyelesaian sengketa yang dapat ditempuh melalui pengadilan atau di luar pengadilan. Dalam memilih penyelesaian sengketa konsumen di luar pengadilan dapat dilakukan melalui beberapa model penyelesaian sengketa, diantaranya melalui Alternative Dispute Resolution (ADR) di Badan Penyelesaian Sengketa Konsumen, Lembaga Perlindungan Konsumen Swadaya Masyarakat, atau melalui Direktorat Perlindungan Konsumen atau lokasi-lokasi lain baik untuk kedua belah pihak yang telah disetujui.

Pengenaan sanksi administratif, sanksi pidana, bahkan hingga sanksi perdata terhadap pelaku usaha yang melanggar peraturan perundanganundangan yang mengatur mengenai Standar Pelayanan Minimal harus dipertegas, mengingat hal tersebut merupakan bentuk perlindungan terhadap pengguna jasa, penumpang, maupun konsumen angkutan umum jenis angkot di Jakarta.

Pemerintah Provinsi DKI Jakarta seharusnya dapat meminimalisir tingkat kejahatan dan pelanggaran terhadap hak-hak konsumen sebagai pengguna jasa maupun penumpang yang sering terjadi dalam angkutan umum jenis angkot di Jakarta dengan melakukan upaya preventif berupa pencegahan terjadinya penambahan angkot baru yang tidak memenuhi standar pelayanan minimal pada saat pendaftaran dan perpanjangan izin trayek yang dikenakan retribusi, dan pada saat retribusi uji KIR di wilayah Provinsi DKI Jakarta sebagaimana diamanatkan dalam Undang-Undang nomor 28 tahun 2009 tentang pajak daerah dan retribusi daerah, serta dalam Perda DKI Jakarta Nomor 3 tahun 2012 tentang retribusi daerah.

\section{Pustaka Acuan}

\section{Buku-Buku}

Aji, Ahmad Mukri. Kontekstualisasi Ijtihad Dalam Diskursus Pemikiran Hukum Islam di Indonesia, Bogor: Pustaka Pena Ilahi, 2010.

Brotosusilo, Agus. et.al., Filsafat Hukum: Semester Genap Tahun Ajaran 2010/2011. Depok: Fakultas Hukum Universitas Indonesia, 2011.

Kamaludin, Rustian. Ekonomi Transportasi. Padang: Ghalia Indonesia, 1986.

Maggalatung, A Salman. "Hubungan Antara Fakta Norma, Moral, Dan Doktrin Hukum Dalam Pertimbangan Putusan Hakim," dalam Jurnal Cita Hukum, Vol. 2, No. 2 (2014).

Maggalatung, A Salman; Yunus, Nur Rohim. Pokok-Pokok Teori Ilmu Negara, Cet1, Bandung: Fajar Media, 2013. 
Marzuki, Peter Mahmud. Penelitian Hukum. Jakarta:Kencana, 2011.

Miru, Ahmadi dan Yodo, Sutarman. Hukum Perlindungan Konsumen. Jakarta: PT. RajaGrafindo Persada, 2008.

Muhammad, Abdulkadir. Arti Penting dan Strategis Multimoda Pengangkutan Niaga di Indonesia Dalam Perspektif Hukum Bisnis di Era Globalisasi Ekonomi. Yogyakarta:Penerbit Genta Press, 2007.

Muhammad, Abdulkadir. Hukum Pengangkutan Niaga. Bandung: PT. Citra Aditya Bakti, 1998.

Nurbaiti, Siti. Hukum Pengangkutan Darat : Jalan dan Kereta Api. Jakarta: Penerbit Universitas Trisakti, 2009.

Rawls, John A. Theory of Justice. Revised Edition, Massachussetts The Belknap of Harvard University Press Cambridge, 1999.

Shofie, Yusuf. Kapita Selekta Hukum Perlindungan Konsumen di Indonesia. Jakarta: PT. Citra Aditya Bakti, 2008.

Soekanto,Soerjono. Penelitian Hukum Normatif. Jakarta; Rajawali Press, 1995.

Soekanto,Soerjono. Pengantar Penelitian Hukum. Jakarta; UI Press, 1986.

Susilo, Zumrotin K. Penyambung Lidah Konsumen. Cet. I. Jakarta: Puspa Swara, 1996.

\section{Jurnal dan Penelitian}

Wulandari, Benadetta T. Busway vs Kemacetan: Tinjauan Atas Hak Konsumen, Jurnal, Lembaga Penelitian dan Pengabdian Kepada Masyarakat, Fakultas Hukum Universitas Katolik Atmajaya, Jakarta.

\section{Artikel}

Majalah Inovasi, Volume 10/XX/Maret 2008, "Reformasi Transportasi Publik di Jakarta: Sebuah Kisah Sukses".

\section{Peraturan Perundang-undangan}

Republik Indonesia. Undang-Undang Nomor 22 Tahun 2009 Tentang Lalu Lintas dan Angkutan Jalan, Lembaran Negara Republik Indonesia Tahun 2009 Nomor 96, Tambahan Lembaran Negara Nomor 5025.

Republik Indonesia. Undang-Undang Nomor 8 Tahun 1999 tentang Perlindungan Konsumen, Lembaran Negara Tahun 1999 Nomor 42, Tambahan Lembaran Negara Nomor 3821. 
Republik Indonesia. Undang-Undang Nomor 14 Tahun 1992 Tentang Lalu Lintas dan Angkutan Jalan, Lembaran Negara Republik Indonesia Tahun 1992 Nomor 49, Tambahan Lembaran Negara Nomor 3480.

Republik Indonesia. Peraturan Menteri Perhubungan Nomor: PM. 81 Tahun 2011 Tentang Standar Pelayanan Minimal Bidang Perhubungan Daerah Provinsi dan Daerah Kabupaten/Kota, Berita Negara Republik Indonesia Tahun 2011 Nomor 560.

Republik Indonesia. Peraturan Menteri Perhubungan Republik Indonesia, Nomor PM. 10 Tahun 2012 Tentang Standar Pelayanan Minimal Angkutan Massal Berbasis Jalan, Berita Negara Republik Indonesia Tahun 2012 Nomor 133.

Republik Indonesia. Peraturan Daerah, Nomor 12 Tahun 2003 tentang lalu Lintas dan Angkutan Jalan, Kereta Api, Sungai, dan Danau serta Penyeberangan di Provinsi DKI Jakarta, Lembaran Daerah Privinsi Daerah Khusus Ibukota Jakarta Tahun 2003 Nomor 87.

\section{Putusan Pengadilan}

Putusan Pengadilan Negeri Jakarta Barat Nomor: 2626/Pid.B/2011/PN.JKT.BAR

Putusan Pengadilan Negeri Jakarta Selatan Nomor 1563/Pid.B/2011/PN.Jkt.Sel

Putusan Pengadilan Negeri Jakarta Selatan Nomor 1560/PID.B/2011/PN.Jkt.Sel

Putusan Pengadilan Negeri Jakarta Selatan Nomor 1561/Pid.B/2011/PN.Jkt.Sel

Putusan Pengadilan Negeri Jakarta Pusat Nomor 1687/PID.B/2012/PN.JKT.PST

\section{Internet}

http://m.skalanews.com/baca/news/2/34/118658/megapolitan/kesadaran-supirangkot-di-jakarta-masih-rendah.html diakses pada 18 September 2012

http://www.ylki.or.id/berlomba-mematikan-angkutan-umum.html diakses pada 15 September 2012

http://www.ylki.or.id/ subsidi-bbm-dan-nasib-angkutan-umum.html diakses pada 18 September 2012

www.dephub.go.id diakses pada 19 September 2012 


\section{Wawancara}

Wawancara dengan Bapak Tulus Abadi, (Pengurus Harian YLKI dan Anggota Dewan Transportasi Kota Jakarta) di Jakarta, Personal Interview, pada 12 April 2013.

Wawancara dengan Bapak Baihaqi, Selaku Kepala Seksi Angkutan Orang Dalam Trayek Dinas Perhubungan Provinsi DKI Jakarta, Personal Interview, pada 14 Juni 2013. 